\title{
Effects of a Feeding Guide Education Program for Parents of Children with Cerebral Palsy
}

\author{
Seon-Yeong Hong ${ }^{\mathrm{a}, \mathrm{b}}$, Seung-Mi Kim ${ }^{\mathrm{c}}$, Ran Lee ${ }^{\mathrm{c}}$, Eun-Ju Lee $^{\mathrm{d}}$ \\ ${ }^{a}$ Graduate School of Special Education, Dankook University, Yongin, Korea \\ ${ }^{b}$ Department of Rehabilitation Medicine, Seoul Metropolitan Children's Hospital, Seoul, Korea \\ 'Department of Speech-Language Pathology, Graduate School, Dankook University, Yongin, Korea \\ ${ }^{d}$ Department of Special Education, Dankook University, Yongin, Korea
}

Correspondence: Eun-Ju Lee, PhD

Department of Special Education, Dankook

University, 152 Jukjeon-ro, Suji-gu, Yongin 16890,

Korea

Tel: +82-31-8005-3818

Fax: +82-31-8019-7139

E-mail: slplee@dankook.ac.kr

Received: January 15, 2016

Revised: April 19, 2016

Accepted: May 17, 2016

This work is based on the master's thesis of the first author.

Special thanks to professor So-Yong Choi. Her detailed comments have helped us substantially.

\begin{abstract}
Objectives: The purpose of this study was to examine the effects of a feeding guide education program for parents of children with cerebral palsy. Methods: Seven pairs of parents and primary caregivers, with 2- to 3-year-old children with cerebral palsy who had difficulties in feeding, were provided with five sessions of feeding guide education. A comparative analysis was made before the education sessions began and 2 weeks after their completion. Feeding assessments were made in the following categories: feeding environment, oral sensitivity, oral function, mobility, and feeding function. Results: After the parental education the feeding environment improved but oral sensitivity oral sensitivity decreased. Oral function and mobility and the feeding functions of the children improved. Conclusion: The parental education used in this clinical practice is expected to help improve feeding functions of children with cerebral palsy through the incorporation of feeding treatment at home.
\end{abstract}

Keywords: Cerebral palsy, Parental education, Feeding environment, Oral sensitivity, Oral function and mobility, Feeding function
뇌성마비는 감각운동계의 질환으로 출생 전, 출생 중 또는 출생 후 몇 년 이내에 일어나는 뇌손상이나 뇌의 발달 이상에 의해 운동, 자세 및 균형과 관련된 다양한 장애를 동반한다(Geralis, 1998;

Kaneko, Mukai, \& Omoto, 1987; Sullivan \& Rosenbloom, 2004). 뇌성마비 아동은 뇌손상이나 뇌의 발달 이상에 의해 비정상적인 근육의 긴장도와 아동의 연령에서 소실되어야 하는 비정상적인 반 사가 남아있어 비정상적인 운동 패턴을 습득하게 된다(Kwon \& $\mathrm{Kim}, 1997)$. 이러한 비정상적인 운동 패턴은 수의적 움직임에 보상 움직임이 함께 나타나 정상적인 발달 과정에 방해를 가져온다. 비 정상적인 운동 발달은 비정상적인 자세 긴장도, 비정상적인 구강 민 감성, 제한된 구강기능운동성에 영향을 미친다(as cited in M. N. Woo, 2004).

뇌성마비 아동의 섭식 발달은 연령, 음식 문화, 음식 재질 및 섭식 방법과 같은 일반적인 요인 이외에도 비정상적인 발달에 따른 신체 기능의 이상, 미성숙한 구강 기능, 비정상적인 구강 반사, 경기와 같
은 개인적인 요인에 의해서 영향을 받는다(Kim et al., 2008; Sullivan \& Rosenbloom, 2004). 이러한 요인들로 인해 뇌성마비 아동들 의 섭식기능 발달이 지연된다. 뇌성마비 아동은 섭식 기능 발달이 지연되면서 제한된 구강 움직임만으로 식사하기 때문에 연령이 증 가할수록 이상 패턴화가 고착화된다(Kaneko et al., 1987). 그래서 뇌성마비 아동은 정상 아동에 비해 2-15배 정도의 식사시간이 필 요하고 음식 섭취량도 적어 전반적인 영양 불균형을 초래하게 된다 (Gisel \& Patrick, 1988).

뇌성마비 아동의 섭식에 영향을 주는 주요 요인에는 섭식 환경, 구강 민감도, 구강기능운동성, 섭식 기능, 비정상적인 구강 반사가 있다(Choi, Kim, Kim, \& Park, 2009; Kaneko et al., 1987; Kim, Bae, \& Cho, 2009; Kim, 2005; Kim, 2000; Kim, Ahn, \& Kwon, 2008; Kim, Ahn, Lee, \& Kwon, 2010; M. N. Woo, 2004; J. Y. Woo, 2004). 각 요인별로 살펴보면, 첫째, 섭식 환경이 섭식에 영향을 줄 수 있다. 섭식 환경에는 섭식 시 부모의 태도, 분위기, 섭식 도구, 섭식 자세 
등이 포함된다(Kaneko et al., 1987). 아동에게 적절한 섭식 환경은 섭식에 도움을 줄 수 있다. 섭식 기능을 촉진하기 위해서는 아동이 자발적으로 먹으려고 해야 하기 때문에 섭식에 대한 흥미와 즐거움 을 유지할 수 있도록 부모는 아동을 배려해야 한다. 그리고 아동이 사용할 섭식 도구는 아동의 구강 크기를 고려해서 선택해야 한다. 너무 큰 섭식 도구를 사용하게 되면 아동의 입 안에 상처를 낼 수 있고 한 번에 너무 많은 음식량이 입 안으로 들어가기 때문에 구강 움직임이 제한된다(Eom, 1992). 아동의 섭식 자세 역시 비정상적인 근 긴장도를 유발시키지 않는지 살펴봐야 한다(Kaneko et al., 1987). 섭식 환경과 관련된 연구들을 살펴보면 $\mathrm{Kim}$ (2005)의 연구에서는 반사억제자세를 이용한 섭식 지도를 통해 아동들의 구강운동능력 과 섭식 기능을 향상시켰고, $\operatorname{Kim}$ (2000)의 연구에서는 자세 조정 프로그램을 활용한 조음기관 훈련을 통해 구강운동능력을 향상시 켰다. 그 외에도 뇌성마비 아동의 식사도구 사용능력에 따라 아동 의 성장과식품 섭취간에 높은 상관관계가 있다고 조사되었다(Kim et al., 2009).

둘째, 비정상적인 구강 민감도가 섭식에 영향을 줄 수 있다. 뇌성 마비 아동은 감각자극의 부족이나 과잉으로 인해 비정상적인 구강 민감도를 보인다. 비정상적인 구강 민감도는 섭식 도구나 음식물이 구강이나 구강 주변에 닿을 때 비정상적인 근 긴장을 발생시켜 섭 식에 어려움을 준다(Kaneko et al., 1987). 구강 민감도와 관련된 연 구들은 상반된 결과를 보고하고 있다. Gisel (1994)은 구강 민감도 가 높은 뇌성마비 아동에게 감각운동치료를 실시한 결과, 구강 민 감도가 낮아져 전반적인 섭식 능력의 증진을 가져온다고 하였지만 Choi 등(2009)은 뇌성마비 아동의 씹기 능력 관련 요인 중 하나인 비정상적인 감각이상이 뇌성마비 아동의 씹기 능력에 영향을 미치 지 않는다고 하였다. Choi 등(2009)은 비정상적인 감각이상을 평가 할 때 평가자가 아닌 아동의 보호자가 평가했기 때문에 평가의 객 관성과 정확성이 낮다는 한계점을 연구 결과에 기술하였다.

셋째, 구강기능운동성이 섭식에 영향을 줄 수 있다. 구강기능운 동성과 섭식 지도 간의 상관관계를 살펴보면 M. N. Woo (2004)의 연구에서는 7-8세 뇌성마비 아동을 대상으로 섭식 훈련을 실시하 였을 때 입술, 혀, 턱의 구강기능운동성이 향상되었다. 섭식은 구강 조음기관들 사이의 협응과 정교한 움직임들이 반복되어야 하기 때 문에 구강기능운동성과 밀접한 관련이 있다. 이에 Kim과 Ahn 등 (2008), Kim 등(2010)은 5-12세 경직성 뇌성마비 아동 17명을 대상 으로 섭식 기능 평가를 한 뒤 조음 능력 간의 상관관계를 살펴보았 다. 그 결과 숟가락으로 먹기와 저작하기는 조음정확도와 상관이 있었다(Kim, Ahn, et al., 2008). 조음 정확도와 섭식 기능은 구강기 능운동성에 영향을 받으므로 구강기능운동성이 좋을수록 섭식
기능과 조음정확도에는 긍정적인 영향을 미쳤다(Kim, Ahn, et al., 2008). 그 후속 연구에서는 경직성 뇌성마비 아동과 정상 아동들의 하위 섭식유형에 따른 구강기능운동성 차이를 살펴보았다(Kim et al., 2010). 그 결과 경직성 뇌성마비 아동은 정상 아동에 비해 섭식 유형에 따른 구강기능운동성에 제한이 있었다.

넷째, 섭식 기능이 섭식에 영향을 줄 수 있다. 아동의 섭식 기능의 발달은 성장과 관련된 해부학적 변화의 영향과 경험적 학습과 관련 된 중추신경계의 발전적 변화에 의해 이루어진다(Crickmay, 1966). 그래서 아동 발달기에 뇌에 장애가 있으면 섭식에 필요한 근육들 간의 협응이 어려워진다. 아동이 섭식 시 수의적인 움직임이 어려 우면 음식을 입 안에 넣고 삼키는 것에 문제가 생겨 섭식 기능에 부 정적인 영향을주고 섭취에 문제가 생기게 된다(Kaneko et al., 1987).

네 가지 변인 이외에도 비정상적인 구강 반사가 섭식에 영향을 줄 수 있다. 뇌성마비 아동의 비정상적인 구강 반사는 턱 떠밀기, 혀 떠밀기, 긴장성 물기 반응, 혀 뒤당김, 비강 역류 등으로 섭식에 필요 한 정상적인 구강 움직임을 방해하게 된다(Love, 2000; Workinger, 2005).

부모는 아동들에게 가장 많은 영향력을 줄 수 있는 교사로 이들 의 가치관이나 신념은 양육방식의 차이를 가져온다(Cho, 2006; Lee \& Lee, 1997). 이에 부모교육은 아동의 인지발달과 정서발달 에 부모의 역할이 중요하다는 것을 인지시키고, 아동에게 제공되 는 교육환경을 효율적으로 구성하는 데 목적이 있다(Lee \& Lee, 1997). 특히 장애 아동의 부모들은 장애 아동의 출생을 예상하지 못한 상태에서 아동의 장애를 수용하고 교육과 양육까지 담당해 야 하기 때문에 정상 아동의 부모가 감당해야 할 부모의 역할보다 그 범위가 크고 광범위하다(Cho, 2006). 그렇기 때문에 장애 아동 부모를 대상으로 부모교육을 실시할 때는 아동의 발달단계에 따른 부모의 역할을 정확히 인지시키고 장애 유형에 따른 부모교육이 이루어져야 한다(Chang, Shim, \& Ko, 2013). 이러한 교육은 조기 치료의 효과를 높일 수 있으며, 치료가 가정까지 연계되는 일관성 을 유지할 수 있다(Koo, Kim, \& Kim 1998).

Kim과 Lee (2013)의 연구에서 부모교육에 관한 연구 동향을 살 펴본 결과, 부모교육 방법으로는 강의와 토론이 많이 활용되었고, 교육 주제로는 양육이나 교육에 대한 지식 및 정보, 양육이나 의사 소통 기술, 아동의 심리 및 정서에 대한 내용이 대부분이었다. 하지 만 장애 아동 부모들은 현재 자신이 어려워하고 궁금한 점을 바로 해결해줄 수 있고 바로 적용할 수 있는 교육을 제공받고 싶어했다. 그렇기 때문에 섭식에 어려움이 있는 장애 아동의 섭식 지도는 치 료실뿐 아니라 가정에서도 이루어질 수 있도록 교육을 해야 양육 하는 부모에게 도움이 되고 치료 효과도 일관성 있게 유지시킬 수 
있다. 부모의 능동적인 참여를 이끈 부모교육에 관한 연구들을 살 펴보면, 뇌성마비 아동의 부모를 대상으로 재활운동 방법에 대한 부모교육을 실시한 이후 아동의 운동발달에 효과가 나타났고(Kim \& Lee, 2012) 중도 뇌성마비 유아를 둔 어머니를 대상으로 의사소 통 기술에 대한 부모교육을 실시한 이후 아동의 비상징적 의사소 통 기술이 증가하여, 어머니의 중재 만족도가 높아졌다(Park \& Kim, 2006).

지금까지 이루어진 섭식 지도에 관한 연구들을 살펴보면, Yang과 Chung (2007)의 연구는 성장장애를 진단받은 정상발달 여아 2명 을 대상으로 행동 수정에 의한 섭식 지도를 했기 때문에 뇌성마비 아동과 그 부모에게 적용하기 어렵다. M. N. Woo (2004)의 연구는 치료사의 중재와 부모교육을 함께 진행하였고, Clawson, Kuchinski와 Bach (2007)의 연구는 1세 6개월에서 4세 7개월에 해당하는 8 명의 뇌성마비 아동을 대상으로 구강운동, 행동 중재, 부모교육을 함께 실시했을 때의 섭식 지도 효과를 살펴보았기 때문에 부모교 육만의 효과로 보기에는 어려움이 있다. 섭식 지도와 관련된 국내 연구들은 대부분 연구자가 직접 섭식 지도를 한 뒤 중재 효과를 보 여주었다(Kim, 2005; M. N. Woo, 2004; J. Y. Woo, 2004). 이처럼 뇌 성마비 아동의 주 양육자에게 섭식 지도와 관련된 부모교육을 실 시한 뒤 직접 중재하게 하여 그 효과를 확인한 연구는 현재까지 미 미한 실정이다(M. N. Woo, 2004; Yang \& Chung, 2007).

정상아동의 섭식 발달도 성인과 같이 정교화되기까지 36 개월 정 도 걸린다. 따라서 이 시기에 섭식 발달이 지연된 아동에게 올바른 섭식 지도를 하는 것이 섭식 발달이 끝난 3 세 이후에 하는 것보다 효과적이다. 그러나 국내외 뇌성마비 아동의 섭식 지도 중재 연구 들은 대부분 만 5-12세를 대상으로 섭식 기능과 조음 능력 간의 상 관관계를 살펴보기 위한 연구들로, 만 2-3세 뇌성마비 아동을 대상 으로 한 연구는 부족한상황이다. 따라서 만 2-3세 뇌성마비 아동을 대상으로 한 섭식 지도 효과를 확인하는 연구가 필요하다(Kaneko et al., 1987).

이에 본 연구는 만 2-3세 뇌성마비 아동의 주 양육자를 대상으로
섭식에 영향을 줄 수 있는 섭식 환경, 구강 민감도, 구강기능운동 성, 섭식 기능과 관련된 내용을 교육한 뒤 주 양육자가 뇌성마비 아 동에게 직접 중재하였을 때 나타나는 효과를 알아보고자 하였다.

\section{연구 방법}

\section{연구대상}

본 연구는 섭식에 어려움이 있는 2-3세 뇌성마비 아동과 주양육 자 7 쌍을 대상으로 하였다. 서울 소재 병원 1 곳에 섭식 지도에 관한 부모교육 안내문을 게시한 뒤 지원하는 양육자를 대상으로 10 분 정도 전화면담을 통해 대상자 선정 기준에 부합한 양육자와 아동 을 선정하였다.

뇌성마비 아동의 선정기준은 다음과 같다. (1) 병원에서 재활의 학과 의사에게 뇌성마비로 진단을 받은 아동이어야 한다. (2) 언어, 운동발달 지체 및 비정상적인 구강기능 운동성을 제외하고 시각, 청각, 정서적인 문제가 없어야 한다. (3) 섭식 기능이 생활연령이 같 은 정상아동에 비해 지연되어 섭식에 어려움이 있으며 섭식 훈련이 나 구강 치료 경험이 없어야 한다. (4) 아동 스스로 섭식 도구를 사 용하기 어려워 섭식 시 양육자의 도움이 필요한 아동이어야 한다. 양육자의 선정기준은 다음과 같다. (1) 교육내용과 관련된 과제를 가정에서 매일 20 분씩 실천할 수 있어야 한다. (2) 아동과 매일 최소 8 시간 이상 함께 지내야 하며, 하루 세 끼 식사중 두 끼 이상을 먹이 는 양육자여야한다.

사전 평가 전 양육자에게 연구에 참여하는 기간 동안 본 연구 이 외의 구강 치료나 섭식 훈련을 받지 않아야 한다는 내용을 미리 공 지하였고, 사후 평가 전에 공지된 내용을 잘 이행했는지 양육자에 게 확인하였다.

위의 기준에 따라 선정된 아동에 대한 정보는 Table 1에 제시하 였다.

사전평가에서 $\mathrm{A}$ 아동은 경직형 뇌성마비 아동으로 섭식 형태는 이유식 후기였으며 물은 스푼을 이용하여 줬을 때 먹을 수 있었다.

Table 1. Information of the children with cerebral palsy

\begin{tabular}{|c|c|c|c|c|c|}
\hline Subject & Sex & Age (yr;mo) & Disability type & $\mathrm{FF}$ & Etc. \\
\hline$A$ & Boy & $2 ; 3$ & Spastic cerebral palsy & $\mathrm{LF}$ & Premature birth \\
\hline$B$ & Boy & $3 ; 3$ & Spastic cerebral palsy & $\mathrm{LF}$ & Premature birth \\
\hline C & Boy & $2 ; 2$ & Spastic cerebral palsy & $\mathrm{EF}$ & Premature birth \\
\hline D & Boy & $2 ; 9$ & Spastic cerebral palsy & LF & Premature birth \\
\hline$E$ & Boy & $2 ; 2$ & Spastic cerebral palsy & $\mathrm{EF}$ & Premature birth \\
\hline F & Girl & $2 ; 8$ & Spastic cerebral palsy & MF & Premature birth \\
\hline G & Boy & $2 ; 5$ & Infantile cerebral palsy, unspecified & $\mathrm{LF}$ & Agenesis of corpus callosum \\
\hline
\end{tabular}

$F F=$ feeding form; $L F=$ late baby food; $E F=$ early weaning food; $M F=$ medium term baby food. 
아동은 다른 신체 부위에 비해 구강 주위에 대한 민감도가 높았고 음식을 먹을 때 구강 폐쇄가 이루어지지 않아 음식 잔여물이 구강 밖으로 나왔다. B아동은 경직형 뇌성마비 아동으로 섭식 형태는 이유식 후기였으나 음식물을 거의 씹지 않고 바로 삼키는 모습이 관찰되었다. 물은 스푼이나 약병을 이용하여 줬을 때 먹을 수 있었 다. 아동은 음식을 먹을 때 구강 폐쇄가 이루어지기는 하나 유지하 는 힘이 약해 음식 잔여물이 입 주변에 묻었다. C아동은 경직형 뇌 성마비 아동으로 섭식 형태는 이유식 초기였다. 하지만 부모 보고 에 의하면 1년 전까지 이유식 후기였다고 한다. 약물 부작용으로 인 해 1 개월 동안 음식만 먹으면 구토를 한 이후 음식에 대한 거부감 이 생겨 젖병으로 우유만 먹다가 최근에 초기 이유식을 시작하였 다고 한다. 아동은 구강 민감도가 높고 음식에 대한 거부감이 심해 평가 시 음식이 구강 안으로 들어갔을 때 울면서 입을 다물지 않았 다. $\mathrm{D}$ 아동은 경직형 뇌성마비 아동으로 섭식 형태는 이유식 후기 였다. 아동은 다른 대상자들에 비해 구강 자극에 대한 거부감이 없 었고, 다양한 섭식 방법(숟가락, 컵)으로 음식을 섭취하고 있었다. 하지만 음식을 먹고 난 뒤 구강 주변에 잔여물을 묻히거나 흘리는 모습을 보였다. $\mathrm{E}$ 아동은 경직형 뇌성마비 아동으로 섭식 형태는 이 유식 초기였으며, 물은 젖병이나 스푼을 이용해서 먹을 수 있었다. 아동은 구강 민감도가 높았고 음식을 먹을 때 구강 폐쇄가 잘 이루 어지지 않아잔여물이 구강 밖으로 나왔다. F아동은 경직형 뇌성마 비 아동으로 섭식 형태는 이유식 중기였으며 물은 스푼이나 약병 을 이용해서 먹었다. 아동은 구강 민감도가 높았고 음식을 먹을 때 구강 폐쇄가 이루어지기는 하나 유지에 어려움이 있어 음식 잔여 물이 입술 주변에 묻었다. $\mathrm{G}$ 아동은 뇌량 무형성증에 의한 뇌성마 비 아동으로 섭식 형태는 이유식 후기였고, 물은 젖병이나 스푼을 사용하여 먹었다. 아동은 입술이나 혀 주변의 구강 민감도가 높았 고, 평가 시 음식물에 대한 거부감을 나타내어 울면서 음식물을 삼 키지 않았다.

\section{평가 도구}

본 연구에서 사용한 평가 도구는 뇌성마비 아동을 대상으로 한 사전 및 사후 평가를 위해 제작하였으며 섭식의 영향을 줄 수 있는 네 가지 요인(섭식 환경, 구강 민감도, 구강기능성운동, 섭식 기능) 을 살펴볼 수 있도록 구성하였다. 이 때 각 평가 문항과 평가 기준은 아래와같다.

\section{섭식 환경 평가}

아동의 섭식 환경을 평가하기 위해 Kaneko 등(1987)의 "섭식 기 능의 장애"에서 제안한 바람직한 식사 환경 지도(섭식 자세, 식사
환경, 주 양육자의 태도, 섭식 도구)를 기초로 구성하였다. 평가는 7 문항으로 구성하였고 5 점 척도를 사용하였다. 각 항목에 점수를 준 뒤 합산하여 총점을 적었다. 섭식 환경 평가 총점이 높을수록 바람 직한 섭식 환경이다. 치료사와 양육자가 함께 평가지 문항을 읽으면 서 해당하는 점수를 체크하였다. 평가 기준은 뇌성마비 아동에게 제시된 문항과 같은 환경을 전혀 제공하지 않으면 0점, 일주일에 1-2일 제공하면 1점, 일주일에 3-4일 제공하면 2점, 일주일에 5-6일 제공하면 3점, 매일 제공하면 4점을 주었다.

\section{구강 민감도 평가}

구강 민감도를 평가하기 위해 Kaneko 등(1987)의 "섭식 기능의 장애"에 첨부된 초진용 진찰검사 용지를 참고하여 연구 목적에 맞 게 수정하였다. 평가는 5 문항으로 구성하였고 5 점 척도를 사용하 였다. 아동에게 제공되는 기회는 총 4 번이었다. 각 문항에 점수를 준 뒤 합산하여 총점을 적었다. 구강 민감도 평가 총점이 높을수록 구강 민감도는 낮다. 평가 기준은 치료사의 손이 아동의 신체부위 에 4 번 닿았을 때 매번 민감하게 반응하면 0 점, 4 번 닿았을 때 3 번 민감하게 반응하면 1점, 4 번 닿았을 때 2 번 민감하게 반응하면 2점, 4 번 닿았을 때 1 번 민감하게 반응하면 3 점, 4 번 닿았을 때 전혀 민 감하게 반응하지 않으면 4점을 주었다.

\section{구강기능운동성 평가}

구강기능운동성을 평가하기 위해 M. N. Woo (2004) 연구에서 사용된 구강 조음기관 기능 수행력 평가지를 사용하였다. 이 평가지 는 구강조음기관의 기능선별검사(Oral Speech Mechanism Screening Examination-revised, OSMSE-R; Kim, 1991) 중 일부를 수정 하여 턱, 입술, 혀의 기능만을 평가할 수 있도록 제작되었다. 평가는 13 문항으로 구성하였고 6점 척도를 사용하였다. 아동에게 제공되 는 기회는 총 5 번이었다. 각 문항에 점수를 준 뒤 합산하여 총점을 적었다. 구강기능운동성 평가 총점이 높을수록 구강기능운동성이 좋다. 평가 기준은 치료사가 제시한 행동을 보고 5 번 모두 부정확 한 움직임을 보이면 0 점, 5 번의 기회 중 1 번 정반응이 보이면 1 점, 5 번의 기회 중 2 번 정반응이 보이면 2 점, 5 번의 기회 중 3 번 정반응을 보이면 3 점, 5 번의 기회 중 4 번 정반응을 보이면 4 점, 5 번의 기회 모 두 정반응을 보이면 5 점을 주었다.

\section{섭식 기능 평가}

섭식 기능을 평가하기 위해 $\operatorname{Kim}$ 등(2008), $\operatorname{Kim}$ 등(2010)의 연구 에서 사용된 섭식 기능 평가지의 평가 행동과 평가 문항 일부를 연 구 목적에 맞게 수정하였다. 이 평가는 숟가락으로 먹기 5 문항, 저 
작하기 8 문항, 컵으로 먹기 6 문항으로 구성하였다. 각 평가는 5 점 척도를 사용하였고 아동에게 제공되는 기회는 각각 4 번이었다. 각 영역의 총점을 더해서 합한 뒤 세 영역의 총점을 적었다. 섭식 기능 평가 총점이 높을수록 섭식 기능이 좋다. 평가 기준은 치료사가 제 시한 4 번의 기회 모두 부정확한 움직임을 보이면 0 점, 4 번의 기회 중 1 번 정반응을 보이면 1 점, 4 번의 기회 중 2 번 정반응을 보이면 2점, 4 번의 기회 중 3 번 정반응을 보이면 3점, 4 번의 기회 모두 정반응을 보이면 4점을 주었다.

섭식 평가와 관련된 모든 내용은 교신저자와 박사과정 언어재활 사 2 명의 지도를 받아 제작하였다. 평가 항목별 평가 문항과 행동은 Appendix 1에 제시하였다.

\section{섭식 지도에 관한 부모교육 프로그램}

본 연구의 섭식 지도에 관한 부모교육 프로그램은 Kaneko 등 (1987), Sullivan과 Rosenbloom (2004), M. N. Woo (2004), Chung (1998)의 연구를 참고하여 구성하였다.

1 회기에는 치료사가 양육자에게 교육에 대한 이해를 높이기 위 해 먼저 구강 근육의 위치와 기능에 대해 설명을 한 뒤 구강민감도 와 구강기능운동성 훈련 방법을 교육하였다. 가정에서 식사 시간 이외의 시간에 양육자가 훈련 받은 내용을 아동에게 하루에 2 회 정도 실시하게 하였다. 먼저 구강민감도를 낮추는 훈련은 아동 몸 의 정중앙에서 가장 멀리 떨어진 곳부터 시작하여 점차 중앙에 가 까운 곳으로 진행하도록 하였다. 잇몸 마사지와 구강 바깥쪽 마사지 를 실시할 때는 약한 자극으로 자극부위를 움직이지 않고 5-10분 정도 실시하게 하였다. 구강기능운동성훈련 방법은 Kaneko 등 (1987)의 “섭식 기능의 장애”에서 제시한 번게이드 방식을 기본으 로 본 연구 방식에 맞게 수정하여 실시하였다. 번게이드 방식의 목 적은 구강 내외를 중심으로 입술, 볼, 혀의 근육을 자극하여 빨기, 삼키기, 저작 패턴을 개선하는 데 있다. 수동적 자극법, 반능동적 자극법, 능동적 자극법, 저항법과 같이 4단계로 구분되며 뒤로 갈 수로 훈련 효과가 높아진다. 수동적 자극법은 아동의 참여보다는 연구자가 주도적으로 구강 움직임을 만들어주는 구강 훈련 단계이 고, 반능동적 자극법은 연구자와 함께 아동도 구강 훈련에 적극적 으로 참여하는 구강 훈련 단계이다. 능동적 자극법은 연구자가 시 범을 보여주면 이를 관찰한 아동이 구강 움직임을 모방할 수 있는 단계이다. 마지막으로 저항법에서는 외부로부터 아동의 구강 근육 에 힘을 가하면 그것에 저항을 하면서 근력을 높여가는 단계이다. 본 연구에서는 연구자가 사전 평가에서 나타난 아동의 구강기능운 동성을 고려해 1 단계부터 3 단계까지만 교육을 실시하였다. 훈련 빈 도는 하루 1-2회 식사 전에 실시하며, 1 회 실시 시간은 최소 5 분 이
상으로 10 분을 넘기지 않도록 하였다. 입술 훈련, 볼 훈련, 혀 훈련 의 순서로 진행하며 반드시 턱이 닫힌 상태에서 시작하게 하였다. 치료사는 양육자에게 아동의 구강 상태를 살피게 하고 입 안에 상 처가 있으면 상처 난 부위를 제외하고 훈련을 실시하게 하였다.

2 회기에는 연구자가 양육자에게 올바른 섭식 환경의 중요성에 관해 교육하였다. 연구자가는 양육자에게 섭식 환경에 영향을 미치 는 섭식자세, 음식형태, 주 양육자의 태도, 섭식 도구에 대해 설명한 뒤, 양육자가 부모교육 내용을 바탕으로 아동의 섭식 환경을 점검 하게 하고 개선할 수 있는 부분을 찾게 하여 연구자와 함께 이야기 나눌수 있도록 구성하였다.

3 회기에서 5 회기까지는 섭식 기능과 관련된 섭식 방법을 세 부분 으로 나누어 교육하였다. 3 회기에는 숟가락으로 먹기, 4 회기에는 저작하기, 5 회기에는 컵으로 먹기로 구성하였다. 연구자는 주 양육 자가 뇌성마비 아동에게 먹이는 모습을 관찰한 뒤 이에 따른 피드 백을 주고 올바른 섭식 방법을 교육하는 것으로 구성하였다. 부모 교육 프로그램의 모든 내용은 교신저자와 박사과정 언어재활사 2 명의 지도를 받았으며 제 1 연구자가 진행하였다.

\section{연구 절차}

본 연구를 진행하기 전 서울특별시 어린이병원 기관생명윤리위 원회에서 심사를 받고 승인을 받았다(IRB No. 2015-03-01-01-01). 본 연구는 2015년 2월 말부터 4월 말까지 진행하였으며, 부모교육 은 병원 내에 있는 언어치료실에서 진행하였다. 부모교육 시작 전 사전 검사를 1 회 실시하고 일주일에 2 번씩 3 주에 걸쳐 총 5 회기의 부모교육을 실시하였다. 부모교육이 끝나고 2주 뒤에 뇌성마비 아 동에게 나타난 효과를 알아보기 위해 사후 평가 1 회를 실시하였다. 사전 및 사후 평가와 부모교육 시 아동은 양육자와 함께 교육에 참 여하였다. 사전 평가에서는 아동의 초기 상태를 정확히 파악하기 위하여 섭식 환경과 구강 민감도, 구강기능운동성, 섭식 기능을 평 가하였다. 평가 항목은 Kaneko 등(1987), M. N. Woo (2004), Kim 등(2008), Kim 등(2010)의 연구에서 사용한 평가 도구를 본 연구에 맞게 수정하여 사용하였다. 섭식 환경에 대한 평가는 연구자가 각 항목에 대해 설명하면 양육자가 질문에 대답하는 보고 형식으로 이루어졌고, 나머지 세 영역(구강 민감도, 구강기능운동성, 섭식 기 능)에 대한 평가는 아동에 대한 직접 평가가 이루어졌다.

연구자는 양육자에게 섭식 지도에 관한 내용을 개별적으로 교육 하였다. 연구자는 모든 양육자에게 동일한 교육 자료와 순서로 부 모교육을 진행하였고 교육 내용에 따라 아동에게 직접 구강 마사 지를 실시하고 교육 자료로 준비한 음식을 먹였다. 연구자가 먼저 시범을 보인 뒤 이를 주 양육자가 관찰하게 하였다. 이후 양육자가 
직접 음식 먹이는 모습을 연구자가 관찰하고 피드백을 주었다. 연구 자는 교육내용에 대해 다시 한 번 설명해주면서 가정에서 복습할 수 있는 부모 과제 기록지를 제공하였다. 부모 과제는 공통 과제와 추가 과제로 구성하였다. 공통 과제는 1 회기 교육 내용인 구강민감 도를 낮추는 활동과 구강기능운동성훈련에 관한 내용으로, 추가 과제는 2 회기 섭식 환경, 3 회기 숟가락으로 먹이기, 4 회기 저작하기, 5 회기 컵으로 먹기에 관한 교육 내용으로 구성하였다. 공통 과제는 매회기 제공하였고 추가 과제는 각 회기가 끝난 후 교육 내용에 따 라 별도로 제공하였다. 연구자는 매 회기 교육 시작 전 양육자가 교 육내용에 따라 가정에서 정확하게 실시하였는지 확인하기 위해 지 난 시간에 배운 섭식 방법에 따라 아동에게 음식을 먹이게 하고 부 모 과제 기록지도 확인하였다. 부모 과제 기록지는 Appendix 2에 제시하였다.

사후 평가는 부모교육의 효과를 알아보기 위해 교육이 끝나고 2 주 뒤에 진행하였다. 연구자는 사후 평가 전까지 양육자가 부모교 육 시간에 배운 구강 마사지, 구강기능운동성 훈련, 섭식 방법을 가 정에서 매일 20 분씩 실시하도록 하였다.

평가와 부모교육 프로그램 진행 과정에서 참여하는 아동이 독 립적으로 앉아있기 어려울 경우 Feeder Sitter나 개인용 휠체어와 같은 보조도구를 사용하였다. 그리고 필요한 경우 보호자나 연구 자가 옆에서 안정적인 자세를 유지할 수 있도록 도와주었다. 연구 자는 부모교육 실시 전, 연구의 목적을 양육자에게 충분히 설명한 뒤 연구 참여 동의와 비디오 녹화 동의를 구하였다. 사전 및 사후 평 가와 5 회기 동안 진행되는 부모교육은 삼성 캠코더 SMX-F50BD를 이용해서 녹화하였다.

\section{자료 및 통계 분석}

섭식 환경에 대한 평가와 구강 민감도 평가 그리고 섭식 기능 평 가는 5점 척도로 평가하고 구강기능운동성 평가는 6점 척도로 평 가한 뒤 총점을 구하였다. 구강 민감도 평가는 총점이 높을수록 구 강 민감도가 낮았고, 나머지 평가에서는 총점이 높을수록 기능이 좋았다. 표에는 각 아동들의 교육 전·후 점수와 향상 점수를 넣었 고, 그래프에는 각 평가에 대한 항목별로 아동들의 점수를 합하여 교육 전·후를 비교 분석하였다. 모든 자료는 PASW Statistics 17.0.2 를 사용하여 두 종속표본 $t$-검정(paired $t$-test)을 실시하였다.

\section{타당도 및 신뢰도}

\section{내용타당도}

섭식 평가 항목과 부모교육 내용이 뇌성마비 아동의 섭식 지도 에 적합한지 알아보기 위해 뇌성마비 섭식 훈련 경험이 있는 경력 5
년, 10 년 이상의 언어재활사 2 명에게 내용타당도 검증을 의뢰하였 다. 내용타당도 검증은 5 점 척도를 사용하였으며, 전혀 타당하지 않 으면 1점, 타당하지 않으면 2점, 보통은 3점, 타당하면 4점, 매우 타 당하면 5 점에 체크하도록 하였다. 평가 항목의 내용타당도는 평균 4.5점, 부모교육에 대한 내용타당도는 평균 5점으로 나타났다.

\section{중재 충실도}

연구자의 중재 충실도는 제1연구자 외 뇌성마비 섭식 훈련 경험 이 있는 경력 5 년 이상인 언어재활사 1 명과 함께 각 아동의 부모교 육이 녹화된 전체 동영상 중 선별된 동영상 $60 \%$ 를 사용하여 중재 충실도를 알아보았다. 이를 위하여 대상 아동 7명 중 4명을 무작위 로 선별하여 연구자와 제 1 평가자가 동일한 장소와 시간에 비디오 를 함께 본 뒤 5 점 척도를 사용하여 평가하였고, 평균은 4.3 점으로 나타났다.

양육자의 중재 충실도는 매 회기 제공한 부모과제기록지의 수행 여부로 중재 충실도를 알아보았다. 연구자는 일관적이고 지속적인 중재를 위해 양육자에게 부모교육 후에도 가정에서 매일 20 분씩 과제를 수행하도록 하였으며, 중재가 가정에서도 유지될 수 있도록 사후 평가 전까지 일주일에 2 회씩 전화상담을 통해 과제수행 여부 를 확인하였다. 연구자는 양육자에게 부모과제기록지를 교육 기간 동안 5 장, 교육 기간 이후 2 장을 제공하였고 양육자는 수행 여부에 따라 5점 척도를 사용하여 기록한 뒤 연구자에게 직접 제출하거나 이메일을 통해 제출하였다. 연구자는 각 양육자가 제출한 7장의 평 균 점수로 다시 7 명의 중재 충실도를 구하였다. 그 결과 평균 4 점으 로 나타났다.

\section{평가자 간 신뢰도}

사전 및 사후 섭식 평가 결과에 대한 평가자 간 신뢰도는 녹화된 자료와 연구자가 측정한 평가지를 사용하여 뇌성마비 섭식 훈련 경 험이 있는 경력 5 년, 10 년 이상의 언어재활사 2 명에게 평가자 간 신 뢰도를 측정하였다. 이를 위하여 대상 아동 7 명 중에서 4 명을 무작 위로 선별하여 연구자 외 제 1 평가자, 제 2 평가자가 동일한 장소와 시 간에 비디오를 본 뒤 각 평가자 간 신뢰도를 구하였다. 3 명 중 2 명의 의견이 일치된 결과로 평가자 간 신뢰도를 구하였고 그 결과 평가자 간 일치도는 $96 \%$ 로 나타났다.

\section{연구 결과}

\section{섭식 환경의 변화}

Table 2에서 볼 수 있는 바와 같이 부모교육 전 섭식 환경 점수의 
Table 2. Feeding environment scores and t-test results between pre- and postparental education (total 28 points)

\begin{tabular}{lccc}
\hline & Pre & Post & Improvement \\
\hline Subject A & 16 & 21 & 5 \\
Subject B & 12 & 24 & 12 \\
Subject C & 18 & 26 & 8 \\
Subject D & 19 & 28 & 9 \\
Subject E & 12 & 26 & 14 \\
Subject F & 21 & 24 & 3 \\
Subject G & 13 & 25 & 12 \\
Sum & 111 & 174 & 63 \\
M (SD) & $15.86(3.63)$ & $24.86(2.19)$ & $9.00(3.70)$ \\
$t$ & \multicolumn{4}{c}{} \\
\hline
\end{tabular}

${ }^{*} p<.05$.

Table 3. Oral sensitivity scores and $t$-test results between pre- and post- parental education (total 20 points)

\begin{tabular}{lccc}
\hline & Pre & Post & Improvement \\
\hline Subject A & 6 & 19 & 13 \\
Subject B & 2 & 16 & 14 \\
Subject C & 15 & 20 & 5 \\
Subject D & 20 & 20 & 0 \\
Subject E & 3 & 19 & 16 \\
Subject F & 2 & 20 & 18 \\
Subject G & 5 & 17 & 12 \\
Sum & 53 & 131 & 78 \\
$\mathrm{M}(\mathrm{SD})$ & $7.57(7.09)$ & $18.71(1.60)$ & $11.14(6.39)$ \\
$t$ & \multicolumn{4}{|}{} \\
\hline${ }^{*} p<.05$. & $4.61^{*}$ &
\end{tabular}

- Pre $\quad$ Post

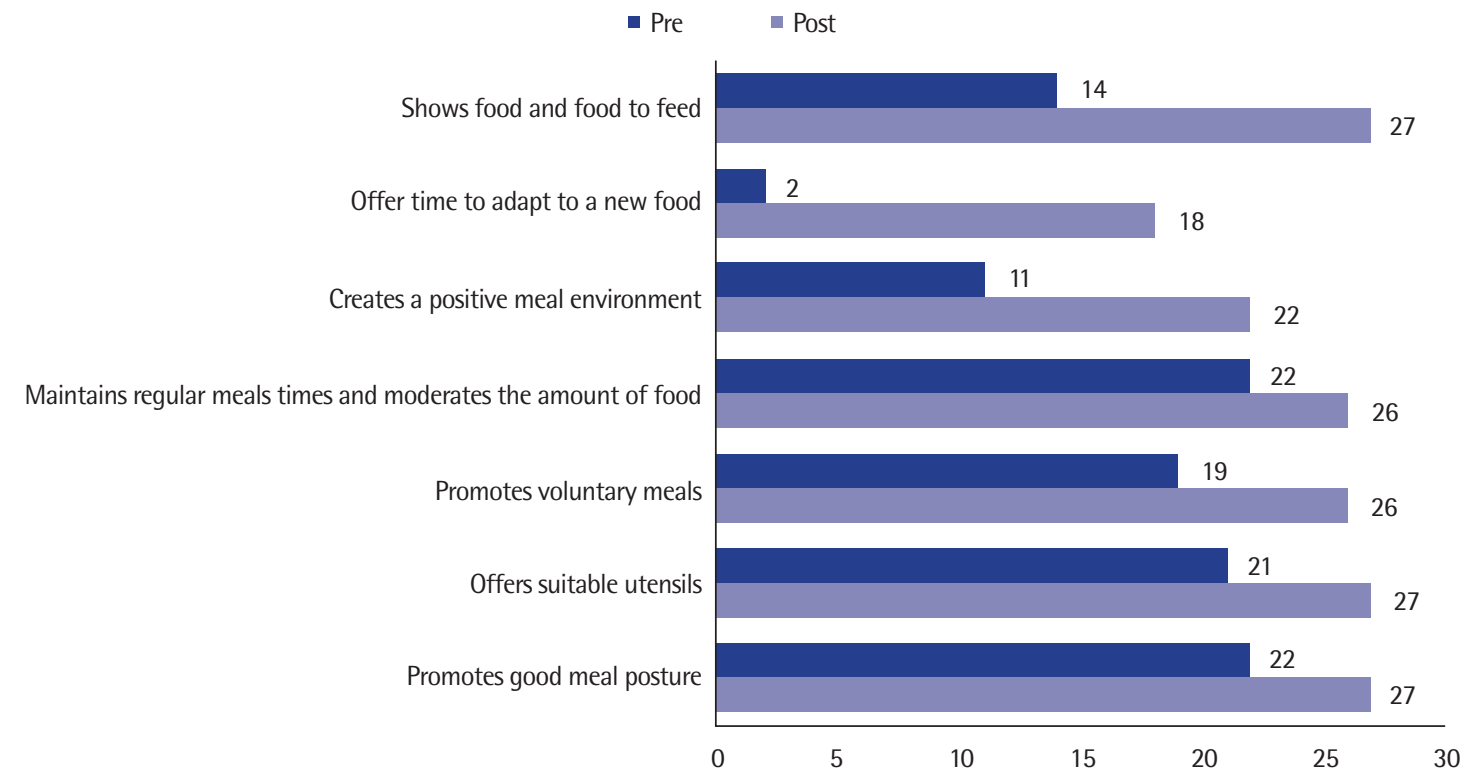

Figure 1. Feeding environment scores pre- and post- parental education (total 28 points).

평균은 15.86점 $(\mathrm{SD}=3.63)$, 부모교육 후 섭식 환경 점수의 평균은 24.86 점 $(\mathrm{SD}=2.19)$ 으로, 부모교육 후의 평균이 부모교육 전보다 9 점 $(\mathrm{SD}=3.70)$ 높아졌다. 이러한 부모교육 전후의 점수 차이는 두 종속표본 $t$-검정 결과 $(t=5.95, p<.05)$, 유의한 것으로 나타났다. 아 동별로 살펴보면, 부모교육 이후 모든 아동의 섭식 환경 점수가 높 아졌다. 가장 큰 점수의 변화(14점)를 보인 아동은 E아동이었고, 가 장 작은 점수의 변화(3점)를 보인 아동은 F아동이었다.

Figure 1에서 볼 수 있는 바와같이 부모교육 후 모든 양육자의 섭 식 환경 제공에 변화가 나타났다. 특히 양육자들은 아동에게 음식 을 바로 먹이지 않고 시각적으로 확인시켜주거나 새로운 음식을 줄 때 이들에게 적응할 수 있는 충분한 탐색 시간을 제공하였다. 또한
즐거운 식사 분위기를 만들기 위해 다른 가족들과 함께 식사를 하 거나 대화를 시도하는 것이 필요하다는 것을 인식하고 개선하였다.

\section{구강 민감도의 변화}

Table 3에서 볼 수 있는 바와 같이 부모교육 전 구강 민감도 점수 의 평균은 7.57점 $(\mathrm{SD}=7.09)$, 부모교육 후 구강 민감도 점수의 평균 은 18.71 점 $(\mathrm{SD}=1.60)$ 으로, 부모교육 후의 평균이 부모교육 전보다 11.14 점 $(\mathrm{SD}=6.39)$ 높아졌다. 이러한 부모교육 전후의 점수 차이는 두 종속표본 $t$-검정 결과, 유의한 것으로 나타났다 $(t=4.61, p<.05)$. 다른 변인들과 달리 구강 민감도 점수는 총점이 높을수록 구강 민 감도가 낮아진다. 아동별로 살펴보면, 부모교육 이후 $\mathrm{D}$ 아동을 제 


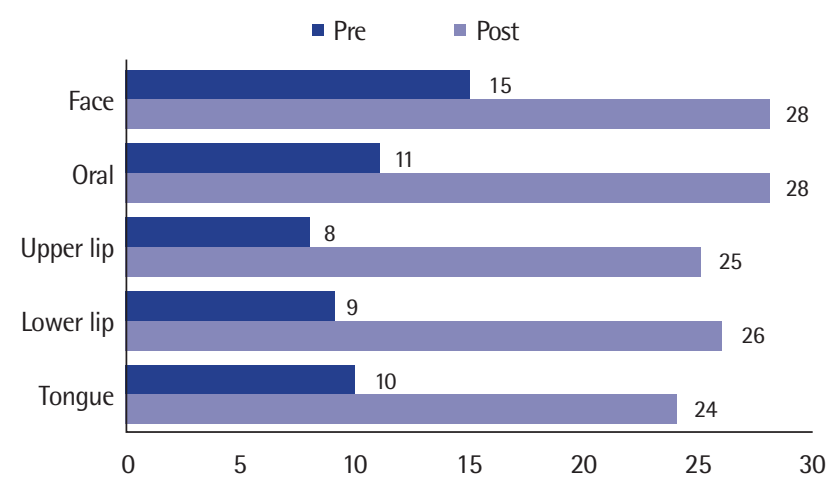

Figure 2. Oral sensitivity scores pre- and post- parental education (total 28 points).

Table 4. Oral functions and mobility scores and $t$-test results between preand post- parental education (total 65 points)

\begin{tabular}{lcccc}
\hline & FF & Pre & Post & Improvement \\
\hline Subject A & LF & 0 & 8 & 8 \\
Subject B & LF & 1 & 4 & 3 \\
Subject C & EF & 0 & 15 & 15 \\
Subject D & LF & 2 & 17 & 15 \\
Subject E & EF & 0 & 4 & 4 \\
Subject F & MF & 2 & 17 & 15 \\
Subject G & LF & 1 & 17 & 16 \\
Sum & - & 6 & 82 & 76 \\
M (SD) & - & $.86(11.71)$ & $.90(6.16)$ & $10.85(5.70)$ \\
$t$ & & & $5.04^{*}$ & \\
\hline
\end{tabular}

$F F=$ feeding form; $L F=$ late baby food; $E F=$ early weaning food; $M F=$ medium term baby food.

${ }^{*} p<.05$.

외하고 모든 아동의 구강 민감도 점수가 높아졌다. 가장 큰 점수의 변화(18점)를 보인 아동은 F아동이었고, 가장 작은 점수의 변화 $(0$ 점)를 보인 아동은 $\mathrm{D}$ 아동이었다.

Figure 2에서는 구강 민감도를 측정한 각 신체 부위에 따라 아동 들의 점수를 합하여 교육 전. 후로 비교하여 살펴보았다. 아동들은 부모교육 이후 얼굴 전체와 구강 주변에 대한 민감도는 현저하게 감소하였고 섭식 도구가 입 주변에 닿았을 때 거부감도 줄어들었다.

\section{구강기능운동성의 변화}

Table 4에서 볼 수 있는 바와 같이 부모교육 전 구강기능운동성 점수의 평균은 .86점 $(\mathrm{SD}=11.71)$ 이고, 부모교육 후 구강기능운동 성 점수의 평균은 .90 점 $(\mathrm{SD}=6.16)$ 으로, 부모교육 후의 평균이 부 모교육 전보다 10.85 점 $(\mathrm{SD}=5.70)$ 높아졌다. 이러한 부모교육 전후 의 점수 차이는 두 종속표본 $t$-검정 결과, 유의한 것으로 나타났다 $(t=5.04, p<.05)$. 아동별로 살펴보면, 부모교육 이후 모든 아동의

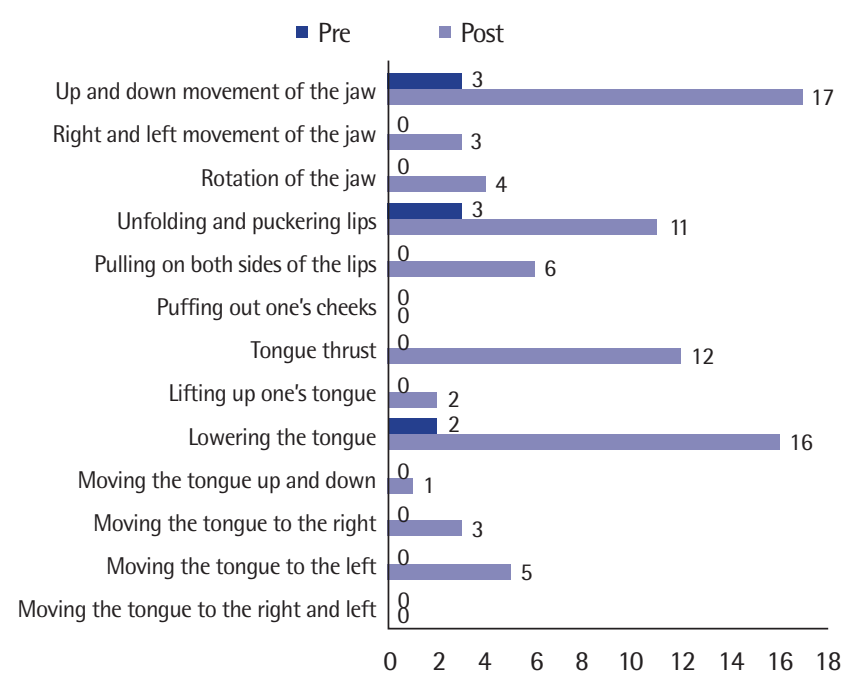

Figure 3. Oral functions and mobility scores of pre- and post- parental education (total 35 points).

구강기능운동성 점수가 높아졌다. 가장 큰 점수의 변화(16점)를 보 인 아동은 $\mathrm{G}$ 아동이었고, 가장 작은 점수의 변화(3점)를 보인 아동 은 $\mathrm{B}$ 아동이었다.

Figure 3에서는 구강기능운동성 평가에서 살펴본 각 항목에 따 라 아동들의 점수를 합하여 교육 전후로 비교하여 살펴보았다. 부 모교육 후 아동들의 턱의 움직임에서는 턱의 상하 움직임, 입술의 움직임에서는 양쪽 입술 꼬리 잡아당기기, 혀의 움직임에서는 혀 아래로 내밀기가 다른 항목에 비해 크게 향상되었다.

\section{섭식 기능의 변화}

Table 5에서 볼 수 있는 바와 같이 숟가락으로 먹기, 저작하기, 컵 으로 먹기로 세분화하여 섭식 기능을 살펴보았다. 그 결과 컵으로 먹기 $(\mathrm{M}=14.43, \mathrm{SD}=6.21)$, 숟가락으로 먹기 $(\mathrm{M}=12.71, \mathrm{SD}=5.95)$, 저작하기 $(\mathrm{M}=7.43, \mathrm{SD}=3.62)$ 순으로 섭식 기능 점수가 향상되었 다. 하지만 이유식 초기 아동의 경우, 숟가락으로 먹기, 컵으로 먹 기, 저작하기 순으로 섭식 기능 점수가 향상되었다.

우선 숟가락으로 먹기에 대한 결과를 살펴보면, 부모교육 전 숟 가락으로 먹기의 평균은 10.14 점( $\mathrm{SD}=7.77)$ 이고, 부모교육 후 숟가 락으로 먹기의 평균은 22.86점( $\mathrm{SD}=6.84)$ 으로, 부모교육 후의 평 균이 부모교육 전보다 12.71점( $\mathrm{SD}=5.95)$ 높아졌다. 이러한 부모교 육 전후의 점수 차이는 두 종속표본 $t$-검정 결과, 유의한 것으로 나 타났다 $(t=5.24, p<.05)$.

Figure 4에서 볼 수 있는 바와 같이 숟가락 먹기에서 아동들은 윗 입술을 내리면서 음식물을 끌어당기는 움직임이 향상되었다. 이는 부모교육 이전에 비해 아동들의 입술 움직임이 향상되었다는 것을 
Table 5. Feeding function scores and $t$-test results between pre- and post- parental education (total 76 points)

\begin{tabular}{|c|c|c|c|c|c|c|c|c|c|c|}
\hline & \multirow{2}{*}{$\mathrm{FF}$} & \multicolumn{3}{|c|}{ Spoon feeding (32 points) } & \multicolumn{3}{|c|}{ Chewing (20 points) } & \multicolumn{3}{|c|}{ Cup feeding (24 points) } \\
\hline & & Pre & Post & IS & Pre & Post & IS & Pre & Post & IS \\
\hline Subject A & $\mathrm{LF}$ & 8 & 18 & 10 & 7 & 15 & 8 & 0 & 16 & 16 \\
\hline Subject B & LF & 5 & 14 & 9 & 0 & 9 & 9 & 0 & 10 & 10 \\
\hline Subject C & $\mathrm{EF}$ & 0 & 24 & 24 & 0 & 11 & 11 & 0 & 17 & 17 \\
\hline Subject D & LF & 19 & 31 & 12 & 10 & 19 & 9 & 15 & 24 & 9 \\
\hline Subject $\mathrm{E}$ & $\mathrm{EF}$ & 7 & 16 & 9 & 2 & 3 & 1 & 0 & 5 & 5 \\
\hline Subject F & MF & 10 & 29 & 19 & 9 & 20 & 11 & 0 & 24 & 24 \\
\hline Subject G & $\mathrm{LF}$ & 22 & 28 & 6 & 7 & 10 & 3 & 4 & 24 & 20 \\
\hline Sum & & 71 & 160 & 89 & 35 & 87 & 52 & 19 & 120 & 101 \\
\hline $\mathrm{M}(\mathrm{SD})$ & & $10.14(7.77)$ & $22.86(6.84)$ & $12.71(5.95)$ & $5.00(4.24)$ & $12.43(6.00)$ & $7.43(3.62)$ & $2.71(5.61)$ & $17.41(7.54)$ & $14.43(6.21)$ \\
\hline$t$ & \multicolumn{4}{|c|}{$5.24^{*}$} & \multicolumn{2}{|c|}{$5.03^{*}$} & \multicolumn{4}{|c|}{$5.69^{*}$} \\
\hline
\end{tabular}

$\mathrm{FF}=$ feeding form; $\mathrm{LF}=$ late baby food; $\mathrm{EF}=$ early weaning food; $\mathrm{MF}=$ medium term baby food; $\mathrm{IS}$ = improvement score. ${ }^{*} p<.05$.

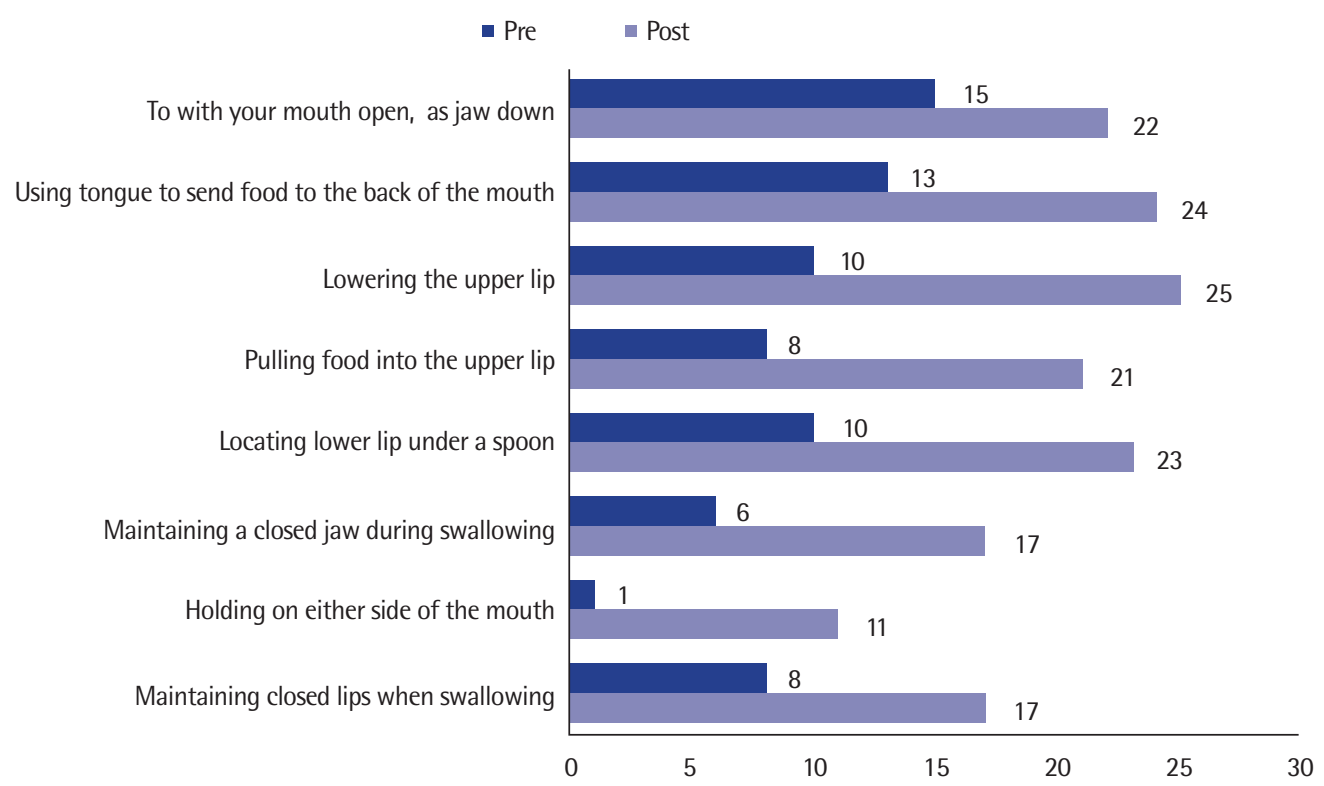

Figure 4. Spoon feeding scores pre- and post- parental education (total 28 points).

알수 있다.

다음으로 저작하기에 대한 결과를 살펴보면, 부모교육 전 저작 하기 점수의 평균은 5.00 점 $(\mathrm{SD}=4.24)$ 이고, 부모교육 후 저작하기 점수의 평균은 12.43 점 $(\mathrm{SD}=6.00)$ 으로, 부모교육 후의 평균이 부 모교육 전보다 7.43점 $(\mathrm{SD}=3.62)$ 높아졌다. 이러한 부모교육 전후 의 점수 차이는 두 종속표본 $t$-검정 결과, 유의한 것으로 나타났다 $(t=5.03, p<.05)$.

Figure 5에서 볼 수 있는 바와 같이 아동들은 저작하기에서 음식 물을 3회 이상 씹고 구강 양쪽으로 옮기는 능력이 향상되었다. 이 는 부모교육 이전에 비해 아동들의 턱과 혀 움직임이 향상되었다 는 것을 알수 있다.
마지막으로 컵으로 먹기에 대한 결과를 살펴보면, 부모교육 전 컵으로 먹기 점수의 평균은 2.71점 $(\mathrm{SD}=5.61)$ 이고, 부모교육 후 컵 으로 먹기 점수의 평균은 17.41점( $\mathrm{SD}=7.54)$ 으로, 부모교육 후의 평균이 부모교육 전보다 14.43 점 $(\mathrm{SD}=6.21)$ 높아졌다. 이러한 부모 교육 전후의 점수 차이는 두 종속표본 $t$-검정 결과, 유의한 것으로 나타났다 $(t=5.69, p<.05)$.

Figure 6에서 볼 수 있는 바와 같이 컵으로 먹기에서 아동들은 컵이 다가오면 입을 벌리고 윗입술을 이용하여 삼킬 수 있는 능력 이 향상되었다. 이는 부모교육 이전에 비해 아동들의 턱과 입술 움 직임이 향상되었다는 것을 알수 있다. 


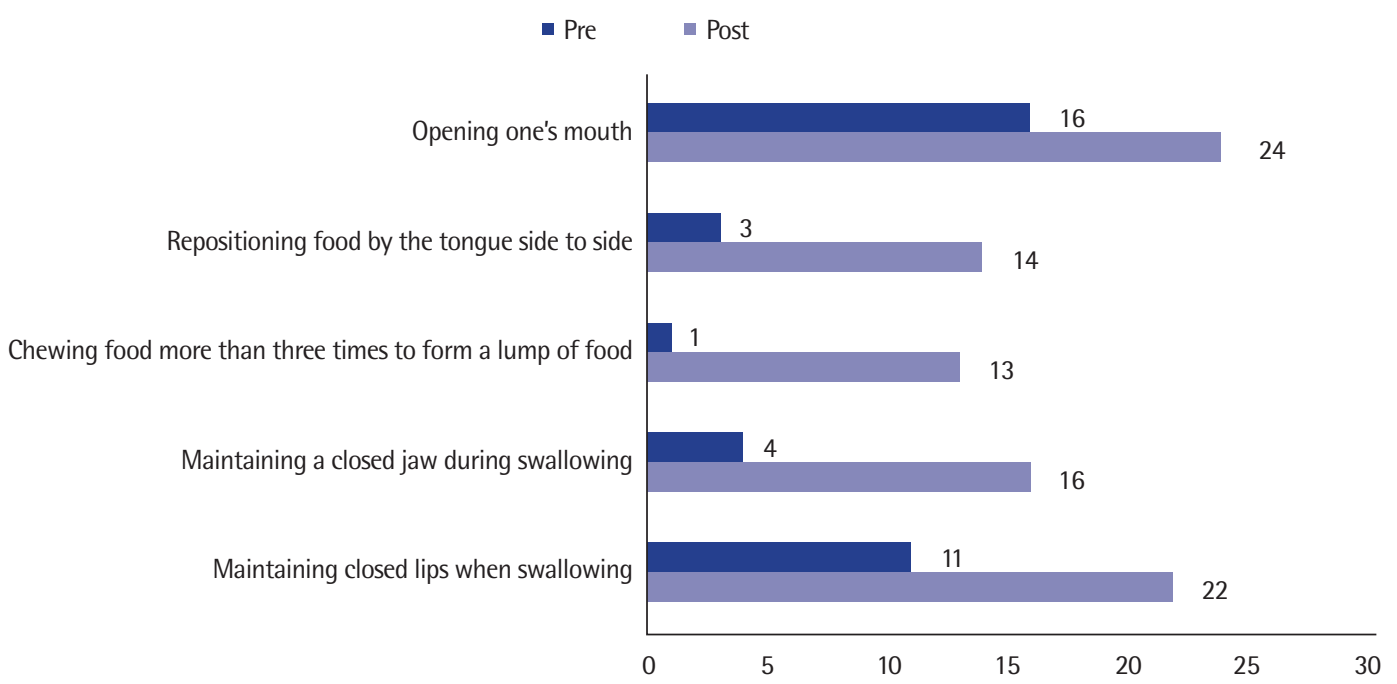

Figure 5. Chewing scores pre- and post- parental education (total 28 points).

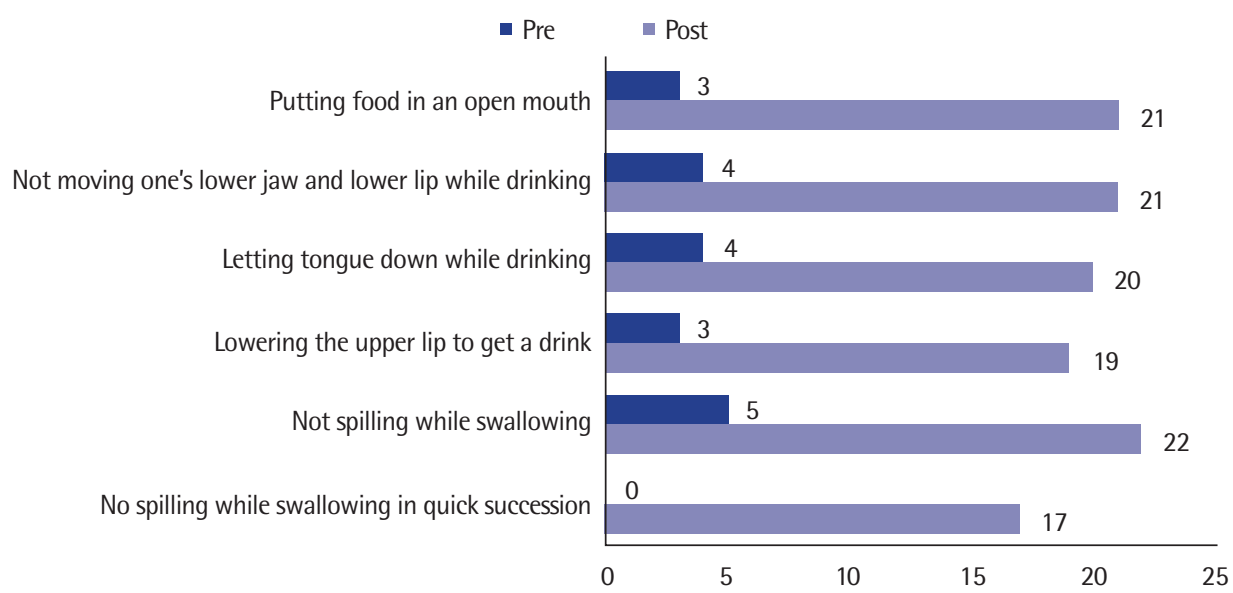

Figure 6. Cup feeding scores pre- and post- parental education (total 28 points).

\section{논의 및 결론}

본 연구는 섭식에 어려움이 있는 뇌성마비 아동을 둔 양육자에 게 섭식에 영향을 줄 수 있는 섭식 환경, 구강 민감도, 구강기능운 동성, 섭식 기능과 관련된 부모교육을 실시하고, 뇌성마비 아동에 게 직접 중재하게 한 후 나타나는 효과를 살펴보고자 하였다. 이를 위해 2-3세 뇌성마비 아동과 주 양육자 7쌍을 대상으로 5회기에 걸 쳐 부모교육을 실시하고 사전·사후 평가를 통하여 비교 분석하였 다. 그 결과는 다음과 같다.

첫째, 섭식 지도에 관한 부모교육 이후 뇌성마비 아동의 섭식 환 경이 개선되었다. 특히 양육자의 섭식 시 태도로 음식을 줄 때 시각 적으로 먼저 확인시켜주기, 새로운 음식을 접할 때 적응할 수 있는
충분한 탐색 시간 주기, 즐거운 식사 분위기 형성하기가 다른 부분 에 비해 많이 향상되었다. 이는 뇌성마비 아동에게 섭식 전 자신이 먹을 음식에 대한 정보를 제공함으로써 심리적, 신체적 준비 시간 을 제공하고, 다른 가족들과 함께 식사를 하거나 즐거운 분위기를 형성해 섭식에 대한 동기를 부여하는 것이 뇌성마비 아동의 섭식에 긍정적인 영향을 미친다는 것을 양육자들이 인식하지 못했기 때문 이라고 추측해 볼 수 있다. 양육자의 태도와 섭식 환경 개선으로 인 해 뇌성마비 아동의 식사 시간이 짧아지고 처음 접한 음식에 대한 거부감도 낮아졌다. 이는 바람직한 섭식 환경이 섭식에 도움을 줄 수 있다는 선행 연구(Kaneko et al., 1987; Kim, 2000; Kim et al., 2009)의 결과와 일치하였다. 섭식 환경은 섭식에 영향을 미치는 네 가지 요인 중 하나로 양육자가 아동의 섭식 환경에 변화를 주는 것 
만으로도 긍정적인 영향을 줄 수 있고, 다른 세 가지 요인에 비해 쉽 게 변화를 줄 수 있는 요인이기 때문에 가정에서 뇌성마비 아동을 양육하는 데 도움이 될 것이다.

둘째, 섭식 지도에 관한 부모교육 이후 뇌성마비 아동의 구강 민 감도가 낮아졌다. 구강 민감도 점수는 다른 세 변인의 점수와는 반 대로 점수가 높을수록 구강 민감도가 낮다. 사전 평가에서 $\mathrm{D}$ 아동 은 총 20 점을 받아 구강 민감도가 낮은 것으로 나타났다. 나머지 아 동들은 연구자의 손이 아동의 구강주위, 입술, 혀에 닿았을 때 4 번 중 3 회 이상의 민감한 반응을 보여 구강 민감도가 높은 것으로 나 타났다. 부모교육 과제를 통해 매일 20 분 이상의 구강민감도를 낮 추는 활동과 구강기능운동성 훈련을 실시한 이후 $\mathrm{D}$ 아동을 제외 한 나머지 아동들은 연구자의 손이 동일한 신체 부위에 4 번 이상 닿았을 때 전혀 민감한 반응이 나타나지 않거나 1 번 민감하게 반응 하는 것으로 나타났다. 그리고 양육자 이외의 연구자나 다른 가족 들이 아동의 구강 주위를 만졌을 때도 거부감이 낮아졌다. 본 연구 에서는, 뇌성마비 아동의 양육자가 구강 민감도를 낮추는 활동을 지속적으로 실시하였을 때, 구강 민감도가 높은 뇌성마비 아동이 이전까지 경험해보지 못한 새로운 종류의 음식을 먹을 수 있게 되 었다. 이러한 결과는 구강 민감도를 낮추는 잇몸 마사지와 구강 바 깥쪽 마사지를 통해 자연스럽게 민감도를 낮출 수 있었기 때문이 다. 따라서 비정상적인 근 긴장도를 가진 뇌성마비 아동들에게 구 강 민감도를 낮추는 활동을 제공한다면 아동의 섭식 발달을 촉진 할 수 있을 것이다.

셋째, 섭식 지도에 관한 부모교육 이후 뇌성마비 아동의 구강기 능운동성의 범위가 향상되었다. 뇌성마비 아동의 턱, 혀, 입술 움직 임이 향상되고 가동범위가 넓어졌다. 부모교육 이후 턱의 움직임에 서는 턱의 상하 움직임, 입술의 움직임에서는 양쪽 입술 꼬리 잡아 당기기, 혀의 움직임에서는 혀 아래로 내밀기가 가능해졌다.

넷째, 섭식 지도에 관한 부모교육 이후 뇌성마비 아동의 섭식 기 능이 향상되었다. 섭식 기능을 숟가락으로 먹기, 저작하기, 컵으로 먹기로 세분화하여 평가한 결과, 아동들은 컵으로 먹기, 숟가락으 로 먹기, 저작하기 순으로 섭식 기능 점수가 향상되었다. 하지만 이 유식 초기 아동들은 이유식 중기나 후기 아동들과는 다르게 숟가 락 먹기, 컵으로 먹기, 저작하기 순으로 섭식 기능이 향상되었다. 이 는 이유식 초기 아동의 경우 숟가락 사용이 이유식 중기나 후기 아 동에 비해 친숙하지 않았지만 섭식 훈련을 하면서 섭식 기능이 향 상된 것으로 추측해 볼 수 있다. 아동들은 컵으로 먹을 때 입을 벌 리고 윗입술을 이용해서 삼킬 수 있게 되었고, 숟가락으로 먹을 때 윗입술로 숟가락 위의 음식물을 입 안으로 끌어당길 수 있게 되었 다. 그리고 입 안으로 들어온 음식을 3 회 이상 씹고 혀를 사용하여
구강 양 옆으로 돌릴 수 있게 되었다. 이러한 결과를 통해 아동들의 혀, 입술, 턱의 운동성이 향상되었다는 것을 알 수 있다. 또한 섭식 기능과 구강기능운동성이 밀접한 관련이 있다는 것을 추측해볼 수있다.

위에 제시한 연구 결과들을 종합해 볼 때 섭식 지도에 관한 부모 교육 이후 모든 아동의 네 가지 변인 점수가 모두 높아졌다. A아동 은 구강 민감도와 섭식 기능에서, $\mathrm{B}$ 아동은 구강기능운동성을 제외 한 나머지 영역에서, C와 D아동은 구강기능운동성과 섭식 기능에 서, $\mathrm{E}$ 아동은 섭식 환경과 구강민감도에서, $\mathrm{F}$ 와 $\mathrm{G}$ 아동은 네 가지 변 인 모두에서 큰 점수의 변화가 나타났다. 이에 따라 연구에 참여한 뇌성마비 아동들의 섭식 환경은 개선되고, 구강 민감도가 낮아지 고, 구강기능운동성과 섭식 기능이 향상되면서 섭식에 도움이 되 었다. 따라서 섭식에 영향을 미치는 네 가지 변인이 뇌성마비 아동 의 섭식에 긍정적인 영향을 주는 것으로 해석할 수 있다. 이러한 결 과는 뇌성마비 아동에게 부모교육을 통한 섭식 지도가 효과적이 라는 M. N. Woo (2004), Yang과 Chung (2007)의 연구 결과를 뒷 받침한다. 부모교육을 통한 중재는 치료실뿐 아니라 가정에서도 치 료가 연계되어 치료의 효과를 더 높일 수 있다. 따라서 임상에서 뇌 성마비 아동의 언어중재 시 양육자를 대상으로 섭식 지도에 관한 부모교육을 실시하고, 이들이 직접 아동에게 실시하게 한다면, 뇌 성마비 아동의 구강기능운동성과 섭식 기능 향상에 도움을 줄 수 있을 것이다.

본 연구 결과를 토대로 한 연구의 제한점 및 후속 연구를 위한 몇 가지 제언은 다음과 같다.

첫째, 본 연구에서는 대상자 수가 7쌍으로 집단의 크기가작고 뇌 성마비 유형은 경직형이 대부분이었다. 그리고 부모교육 전부터 대 상 아동들 간에 구강기능운동성, 구강 민감도, 섭식 기능 능력에 개 인차가 있었기 때문에 섭식 지도에 관한 부모교육의 효과를 일반 화하는 데 제한이 있다. 이후 연구에서는 비슷한 구강 민감도나 구 강기능운동성을 가진 다양한 유형의 뇌성마비 대상자를 충분히 확보하여 섭식 지도에 관한 부모교육의 효과를 밝히는 연구와 부 모교육을 받은 집단과 받지 않은 집단 간의 구강 민감도, 구강기능 운동성, 섭식 환경, 섭식 기능에 차이가 있는지 비교하는 연구가 이 루어진다면 섭식 지도에서 부모 역할의 중요성을 좀 더 명확히 확 인할 수 있을 것이다.

둘째, 본 연구의 부모교육은 개별 프로그램으로 진행되었기 때 문에 집단 프로그램으로 진행되었을 때의 효과를 확인할 수 없었 다. 개별 프로그램은 아동의 특성과 양육자의 욕구를 반영하면서 프로그램을 진행할 수 있지만 연구자에 대한 양육자의 의존도가 높고, 연구자 이외에 다른 사람에게서 정보를 얻을 기회가 적다. 반 
면 집단 프로그램은 다양한 연령, 다양한 섭식 발달단계의 아동과 주 양육자들이 자연스럽게 정보를 교환하고 서로 도움을 줄 수 있 다는 장점이 있다. 따라서 집단 섭식 지도 프로그램과 함께 그 효과 를 확인하는 후속 연구가 필요하다.

셋째, 섭식 지도에 관한 부모교육 이후 일부 대상자에게서 새로 운 음소 산출이 관찰되었다. M. N. Woo (2004)는 섭식 촉진 프로 그램이 7-8세 뇌성마비 아동의 모음 명료도를 향상시키는 데 도움 을 준다고 하였다. Kim 등(2008)과 $\mathrm{Kim}$ 등(2010)은 5-10세 뇌성마 비 아동을 대상으로 섭식 기능과 조음정확도 간의 상관관계를 연 구한 결과 섭식 기능이 좋으면 조음명료도도 높다고 하였다. 이처 럼 선행 연구들은 5 세 이상의 아동들을 대상으로 이루어졌다. 따 라서 후속 연구에서는 2-3세 섭식 지연이 있는 언어이전기 뇌성마 비 아동들을 대상으로 섭식 지도가 미치는 언어적 효과에 대해 살 펴볼 필요가 있다.

넷째, 섭식에 영향을 미치는 변인 중 하나인 비정상적인 구강 반 사는 본 연구에서 제외하였다. 아동의 비정상적인 구강 반사를 연 구자 이외의 다른 평가자가 직접 관찰하기 어려웠고 동영상을 통한 간접 관찰만 가능하여 평가에 어려움이 있었다. 하지만 후속 연구 에서는 비정상적인 구강 반사를 변인으로 추가하여 살펴볼 필요가 있다.

\section{REFERENCES}

Chang, S. A., Shim H. J., \& Ko, D. H. (2013). A study on effective parent education for children with sensory impairments: focused on visual impairment and hearing impairment. Journal of Speech-Language and Hearing Disorders, 22, 303-324.

Cho, Y. T. (2006). A review on parent education of child with developmental disabilities. Journal of the Korean Association on Developmental Disabilities, 10, 5-26.

Choi, M. S., Kim, H., Kim, D. Y., \& Park, E. S. (2009). Factors affecting the chewing ability of children with cerebral palsy. Korean Journal of Communication Disorders, 14, 117-127.

Chung, J. J. (1998). The effect of oral motor training on language ability in children with cerebral palsy. Journal of Speech-Language and Hearing Disorders, 7, 27-46.

Clawson, E. P., Kuchinski, K. S., \& Bach, R. (2007). Use of behavioral interventions and parent education to address feeding difficulties in young children with spastic diplegic cerebral palsy. NeuroRehabilitation, 22, 397-406.

Crickmay, M. C. (1966). Speech therapy and the Bobath approach to cerebral palsy (H. S. Park \& U. W, Rah, Trans.). Seoul: Yonsei University Press.

Eom, T. J. (1992). Feeding behavior of cerebral palsy and down's syndrome children (Master's thesis). Kyungpook National University, Daegu, Korea.

Geralis, E. (1998). Children with cerebral palsy (2nd ed., S. Kim, I. Sung, S. Park, \& H. Jung, Trans.). Bethesda, MD: Woodbine House.

Gisel, E. G. (1994). Oral-motor skills following sensorimotor intervention in the moderately eating-impaired child with cerebral palsy. Dysphagia, 9, 180-192.

Gisel, E., \& Patrick, J. (1988). Identification of children with cerebral palsy unable to maintain a normal nutritional state. Lancet, 331, 283-286.

Kaneko, Y., Mukai, Y., \& Omoto, K. (1987). Disorders in eating function: its concept and application to the rehabilitation program (B. Y. Yoon, Trans.). Daegu: Pope John Paul II Nursery.

Kim, H., Park, E. S., Park J. E., Lee, H. J., Nam J. M., Choi, M. S., ... \& Lee, S. J. (2008). Do gross/fine motor functions and/or non-speech mechanism function affect feeding-swallowing function in children with cerebral palsy? Korean Journal of Communication Disorders, 13, 242-262.

Kim, J. D., Bae, Y. K., \& Cho, M. S. (2009) Eating patterns of children with cerebral palsy by table utensil-handling skills. Journal of the Korean Dietetic Association, 15, 139-151.

Kim, J. G., \& Lee, J. W. (2012). The effect of family support program on gross motor function, support system, and parenting stress in children with cerebral palsy. Journal of Rehabilitation Research, 16, 157-171.

Kim, J. I. (2005). The effects of postural adjustment program for reflex inhibit on feeding \& oral motor function of cerebral palsy (Master's thesis). Daegu University, Gyeongsan, Korea.

Kim, K., \& Lee, M. (2013). The effects of modular parent education program on parenting core competency of the parents of young children with disabilities. Korean Journal of Early Childhood Special Education, 13, 73-95.

Kim, S. H. (2000). The effect of the respiratory and articulatory training program on the postural control for the children with cerebral palsy (Master's thesis). Daegu University, Gyeongsan, Korea.

Kim, S., Ahn J., Lee O. B., \& Kwon, D. (2010). Differences on articulators' function according to feeding subtypes between children with spastic cerebral palsy and normal children. Phonetics and Speech Sciences, 2, 93-100.

Kim, S., Ahn, J., \& Kwon, D. (2008). A correlation studying between feeding skills and percent of correct articulation of the children with spastic cerebral palsy. Journal of Speech-Language and Hearing Disorders, 17, 1-17.

Kim, Y. T. (1991). The Oral Speech Mechanism Screening Examination-Revised. Unpublished. 
Koo, B. K., Kim D. Y., \& Kim Y. Y. (1998). Special education. Seoul: Kyoyook. Kwon, H., \& Kim, Y. (1997). Positioning for play. Seoul: Jeongdam.

Lee, S. Y., \& Lee, S. B. (1997). The educational rehabilitation and welfare by related to parent education of handicapped children. Journal of Rehabilitation Research, 1, 33-60.

Love, R. J. (2000). Childhood motor speech disability. Boston, MA: Allyn \& Bacon.

Park, K. O., \& Kim, Y. W. (2006). Effects of mother's intervention on the nonsymbolic communication skill of young children with severe cerebral palsy. Korean Journal of Special Education, 41, 241-266.

Sullivan, P. B., \& Rosenbloom, L. (2004). Feeding the disabled child (E. U. Na
\& H. Y. Jeong, Trans.). Seoul: Eulyoo.

Woo, J. Y. (2004). The effect of eating training on the development of verbal function of children with cerebral palsy (Master's thesis). Daegu University, Gyeongsan, Korea.

Woo, M. N. (2004). The effect of the feeding program for the children with cerebral palsy (Master's thesis). Daegu University, Gyeongsan, Korea.

Workinger, M. S. (2005). Cerebral palsy resource guide for speech-language pathologists. Clifton Park, NY: Thomson Delmar Learning.

Yang, S. J., \& Chung, K. M. (2007). Parental implementation of behavior intervention program for children with feeding disorder. Journal of Emotion \& Behavior Disorders, 23, 99-117. 
Appendix 1. 섭식 기능 평가

\begin{tabular}{|c|c|c|}
\hline 평가 항목 & 평가문항 & 목표 행동 \\
\hline \multirow{7}{*}{ 섭식 환경 } & 1 & 식사 시 아동에게 말을 걸고, 음식을 보여준 다음 입안으로 가져갔다. \\
\hline & 2 & 식사 시 처음 제공되는 음식에 대해서 5분 이상 탐색할 시간을 주었다. \\
\hline & 3 & 아동이 다른 사람과 함께 식사를 하게 하였다(아동 혼자 식사하는 상황을 만들지 않았다). \\
\hline & 4 & 식사는 일정한 장소와 시간을 정해서 했으며 아동에게 적절한 양(스푼의 둥근 부분에 $1 / 2,2 / 3$ 정도)을 제공하였다. \\
\hline & 5 & 입을 벌리기 전에 무리하게 음식을 넣지 않고, 아동의 반응을 1-2분 기다려주었다. \\
\hline & 6 & 식사 시 제공된 섭식 도구(스푼, 컵)가 아동의 구강크기보다 작거나 크지 않았다. \\
\hline & 7 & 식사 시 아동은 신체의 바른 정렬(alignment)을 유지하였다. \\
\hline \multirow[t]{5}{*}{ 구강민감도 } & 1 & 얼굴전체 \\
\hline & 2 & 구강주위 \\
\hline & 3 & 윗입술 \\
\hline & 4 & 아랫입술 \\
\hline & 5 & 혀 \\
\hline \multirow[t]{13}{*}{ 구강기능 운동성 } & 1 & 상하로 입을 길게 벌린다. \\
\hline & 2 & 좌우로 번갈아 움직인다. \\
\hline & 3 & 회전으로 움직인다. \\
\hline & 4 & 입술을 오므렸다가 편다. \\
\hline & 5 & 양쪽 입술꼬리를 구각으로 잡아당긴다. \\
\hline & 6 & 볼 부풀리기를 한다. \\
\hline & 7 & 양 입술에 접촉되지 않게 입 밖으로 내밀었다가 당긴다. \\
\hline & 8 & 윗입술에 접촉한다. \\
\hline & 9 & 아랫입술에 접촉한다. \\
\hline & 10 & 위아래 입술에 번갈아 접촉한다. \\
\hline & 11 & 오른쪽 구각에 접촉한다. \\
\hline & 12 & 왼쪽 구각에 접촉한다. \\
\hline & 13 & 양 구각에 번갈아 접촉한다. \\
\hline \multirow{8}{*}{$\begin{array}{l}\text { 섭식 기능 } \\
\text { (숟가락) }\end{array}$} & 1 & 숟가락이 입술 주변에 오면 하악이 아래로 내려가고 입술이 벌어진다. \\
\hline & 2 & 음식물이 구강 안으로 들어가면 혀가 구강 뒤쪽에 위치한다. \\
\hline & 3 & 윗입술을 내려와 숟가락 위로 가져간다. \\
\hline & 4 & 윗입술로 숟가락 위의 음식물을 구강 안으로 가져온다. \\
\hline & 5 & 아랫입술을 숟가락 아래에 위치한다. \\
\hline & 6 & 혀와 함께 입술을 이용해 숟가락의 음식물을 구강 양 옆쪽으로 보낸다. \\
\hline & 7 & 턱 회전 움직임이 나타나면서 음식물을 삼키는 동안 턱을 다물고 유지한다. \\
\hline & 8 & 삼키는 동안 양 입술의 폐쇄를 유지한다. \\
\hline \multirow{5}{*}{$\begin{array}{l}\text { 섭식 기능 } \\
\text { (저작하기) }\end{array}$} & 1 & 음식물이 입술 주변에 오면 점차 입을 벌린다. \\
\hline & 2 & 혀로 음식물을 구강 양 옆쪽으로 보낸다. \\
\hline & 3 & 음식물을 3번 이상 씹어 음식 덩이를 형성한다. \\
\hline & 4 & 턱의 회전 움직임이 나타나면서 음식물을 삼키는 동안 턱을 다물고 유지한다. \\
\hline & 5 & 삼키는 동안 양입술의 폐쇄를 유지한다. \\
\hline \multirow[t]{6}{*}{ 섭식 기능(컵) } & 1 & 컵으로 마실 때 윗입술이 주머니 모양을 형성하고 음식물을 입 안으로 끌어당긴다. \\
\hline & 2 & 마시는 동안 하악과 아랫입술의 움직임이 고정된다. \\
\hline & 3 & 마시는 동안 혀가 입 바닥에 위치한다. \\
\hline & 4 & 음료수를 끌어당기기 위해 위 입술을 움직인다. \\
\hline & 5 & 1회 구강으로 유입된 양을 흘리지 않고 삼킨다. \\
\hline & 6 & 연속해서 구강으로 유입된 음료수를 흘리지 않고 삼킨다. \\
\hline
\end{tabular}


Seon-Yeong Hong, et al. • Effects of Feeding Education Parents

Appendix 2. 부모 과제 기록지(구강 민감도를 낮추는 활동과 구강기능운동성 훈련)

구강 마사지와 구강기능운동성 훈련을 매일 10 분씩 2 회 실시해주세요. 그리고 그에 따른 아동의 반응을 간단히 적어주세요.

\begin{tabular}{ccccc}
\hline 날짜 & 유/무 & 시간 & 구강운동기능성 훈련(입술 $\rightarrow$ 볼 $\rightarrow$ 혀) & 구강 민감도 \\
\hline 유/무 & 아침/점심/저녁 & 수동적/ 반능동적/능동적 & 구강 바깥쪽 $\rightarrow$ 구강 안쪽(읫몸 아란응에서 위로) \\
유/무 & 아침/점심/저녁 & 수동적/ 반능동적/능동적 & 구강 바깥쪽 $\rightarrow$ 구강 안쪽(잇몸 아래에서 위로) \\
유/무 & 아침/점심/저녁 & 수동적/ 반능동적/능동적 & 구강 바깥쪽 $\rightarrow$ 구강 안쪽(잇몸 아래에서 위로) \\
유/무 & 아침/점심/저녁 & 수동적/ 반능동적/능동적 & 구강 바깥쪽 $\rightarrow$ 구강 안쪽(잇몸 아래에서 위로) \\
유/무 & 아침/점심/저녁 & 수동적/ 반능동적/ 능동적 & 구강 바깥쪽 $\rightarrow$ 구강 안쪽(잇몸 아래에서 위로) \\
유/무 & 아침/점심/저녁 & 수동적/ 반능동적/능동적 & 구강 바깥쪽 $\rightarrow$ 구강 안쪽(잇몸 아래에서 위로)
\end{tabular}

치료사에게 과제 확인을 받고 점수를 체크해주세요.

1 (과제 못함)

2 (거의 못함)

3 (보통)

4 (가끔 실시)

5 (매일 실시) 


\section{국문초록}

\section{섭식 지도에 관한 부모교육이 뇌성마비 아동에게 미치는 효과}

홍선영 ${ }^{1,2} \cdot$ 김승미 $^{3} \cdot$ 이 란 ${ }^{3} \cdot$ 이은주 ${ }^{4}$

단국대학교 특수교육대학원, ${ }^{2}$ 서울특별시 어린이병원, ${ }^{3}$ 단국대학교 대학원 언어병리학과, ${ }^{4}$ 단국대학교 특수교육과

배경 및 목적: 본 연구는 섭식에 어려움이 있는 2-3세 뇌성마비 아동의 주 양육자 7쌍을 대상으로 섭식에 영향을 줄수 있는 섭식 환경, 구강 민감도, 구강기능운동성, 섭식 기능과 관련된 내용을 교육한 뒤주 양육자가 뇌성마비 아동에게 직접 중재하였을 때 나타나는 효 과를 알아보고자 하였다. 방법: 부모교육 시작 전 사전검사를 1 회 실시하고 5 회기의 부모교육을 실시하였다. 부모교육이 끝나고 2 주 뒤 에 사후평가 1 회를 실시하였다. 섭식 환경, 구강 민감도 및 섭식 기능은 5 점 척도로 평가하고 구강기능운동성은 6 점 척도로 평가한 뒤 교육 전과 교육 후의 점수 차이를 살펴보았다. 결과: 섭식 지도에 관한 부모교육 이후주 양육자가 뇌성마비 아동에게 직접 중재를 실시 한 결과, 뇌성마비 아동의 네 가지 변인 점수가 모두 높아졌다. 연구에 참여한 뇌성마비 아동들의 섭식 환경은 개선되었고, 구강 민감도 는 낮아졌으며, 구강기능운동성과 섭식 기능이 향상되면서 섭식에 도움이 되었다. 논의 및 결론: 임상에서 중증뇌성마비 아동의 섭식 중재 시 이를 적용한다면 구강기능운동성과 섭식 기능 향상에 도움을 줄 수 있고 치료실뿐 아니라 가정에서도 섭식 치료가 연계되어 치료의 효과를 더 높일 수 있을 것이다.

핵심어: 뇌성마비, 부모교육, 섭식 환경, 구강 민감도, 구강기능운동성, 섭식 기능

본 논문은 제 1 저자의 석사학위논문을수정·보완하였음.

논문 진행에 도움을 주신 최소영 교수님께 감사 드립니다.

\section{참고문헌}

구본권, 김동연, 김영욱(1998). 특수교육학. 서울: 교육과학사.

권혁철, 김연실(1997). 운동발달 촉진을 위한 놀이자세지도. 서울: 정담미디어.

김기룡, 이명희(2013). 모듈식 부모교육 프로그램이 장애유아 부모의 양육핵심역량에 미치는 효과. 유아특수교육연구, 13, 73-95.

김선희(2000). 체간과 머리 반사 억제 자세 조정 프로그램을 이용한 호흡 및 조음기관 훈련 프로그램이 뇌성마비 아동의 구어 기초 능력 향상에 미치

는 효과. 대구대학교대학원 석사학위논문.

김선희, 안종복, 권도하(2008). 경직형 뇌성마비 아동들의 섭식 기능과 조음정확도 간의 상관연구. 언어치료연구, 17, 1-17.

김선희, 안종복, 이옥분, 권도하(2010). 섭식 유형에 따른 경직형 뇌성마비 아동과 정상 아동 간의 조음기관 수행력 비교. 말소리와 음성과학, 2, 93-

100.

김영태(1991). 구강조음기관의 기능선별검사. 미간행.

김잔듸, 배윤경, 조미숙(2009). 식사도구 사용능력에 따른 뇌성마비아동의 식생활. 대한영양사협회학술지, 15, 139-151.

김장곤, 이종원(2012). 가족지원 프로그램이 뇌성마비 아동의 신체 기능과 지지체계, 양육스트레스에 미치는 영향. 재활복지, 16, 157-171.

김정임(2005). 반사억제자세프로그램이 뇌성마비 아동의 섭식 기능 향상에 미치는 효과. 대구대학교대학원 석사학위 논문.

김향희, 박은숙, 박지은, 이현정, 남정모, 최명수, 이승진(2008). 뇌성마비 아동의 대·소근육 운동기능 및 비구어기제기능이 섭식-삼킴기능에 미치는

영향. 언어청각장애연구, $13,242-262$.

박경옥, 김영욱(2006). 어머니에 의한 중도 뇌성마비 유아의 비상징적 의사소통 중재 효과. 특수교육학연구, 41, 241-266.

양소정, 정경미(2007). 부모교육을 통한 섭식장애 아동의 행동치료. 정서·행동장애연구, 23, 99-117.

엄태진(1992). 뇌성마비 및 Down 증후군아동들의 섭식 행동 양상. 경북대학교대학원 석사학위논문.

우미남(2004). 섭식 촉진 프로그램이 뇌성마비 아동의 조음기관 운동 기능 개선에 미치는 영향. 대구대학교대학원 석사학위논문. 
우지연(2004). 섭식 훈련이 뇌성마비 언어기능 향상에 미치는 효과. 대구대학교대학원 석사학위논문.

이상복, 이상훈(1997). 장애인 부모교육을 통한 장애인 교육재활과 복지. 재활복지, 1,33-60.

장선아, 심희정, 고도흥(2013). 시각 및 청각장애 아동을 위한 효과적인 부모교육 방안 연구. 언어치료연구, 22, 303-324.

정진자(1998). 구강운동훈련이 뇌성마비 아동의 언어능력에 미치는 효과. 언어치료연구, 7,27-46.

조용태(2006). 발달장애아동 부모의 부모교육에 대한 고찰. 발달장애연구, 10, 5-26.

최명수, 김향희, 김덕용, 박은숙(2009). 뇌성마비 아동의 씹기 능력 관련 요인. 언어청각장애연구, 14, 117-127.

Elaine Geralis (1998). 뇌성마비 아동의 이해(제2판, 김세주, 성인영, 박승희, 정한영 역). 서울: 시그마프레스.

Kaneko Yoshihiro, Mukai Yoshiharu, Omoto Kazuhiko (1987). 섭식기능의 장애: 그에 대한 이해와 리히빌리테이션(윤병완 역). 대구: 요한바오로2

세어린이집.

Marie C. Crickmay (1966). 뇌성마비의 언어치료: Bobath 치료법의 개요(박혜숙, 나은우 역). 서울: 연세대학교 출판부.

Peter B. Sullivan, Lewis Rosenbloom (2004). 장애아동의 섭식(나은우, 정한영 역). 서울: 을유문화사. 